\title{
EFEK PENGGUNAAN PUPUK ORGANIK DAN INOKULAN MIKROBATERHADAP PERTUMBUHAN JATI SUPER (Tectona grandis L.f.) PADA LAHAN BEKAS TAILING POND PENAMBANGAN EMAS DI CIKOTOK
}

\author{
Dyah Supriyati dan Dwi Agustiyani \\ Bidang Mikrobiologi, Pusat Penelitian Biologi - LIPI \\ JI. Raya Bogor-Jakarta Km. 46 Cibinong 16911, Tel 021-8765066, Fax 8765062
}

\begin{abstract}
Experiment using organic fertilizer and microbial community to support the growth of Tectona grandis L. fin the cyanide contaminated-soil has been conducted in gold tailing pond Cikotok. Microbes used in this experiment were mixed of cyanide degradingbacteria, Nitrogen fixing-bacteria, and Phosphat solubilizing-bacteria. The results show that the microbes given in the Tectona grandis L.f plantation was significantly supporting the growth of the plants and reduced cyanide from the contaminated soil, but did not influence the microbe population of the soil.
\end{abstract}

Key word: Phytoremediation, Cyanide, Tectona grandis L.f.

\section{PENDAHULUAN}

Penambangan emas PT ANTAM, Cikotok merupakan penambangan emas bawah tanah (underground mining), menggunakan sianida untuk memisahkan emas dari logam lainnya. Lumpur buangan bekas penambangan emas tersebut selain mempunyai potensi pencemaran sianida juga mempunyai tingkat kesuburan yang sangat rendah. Hasil analisa kandungan bahan organik yang dilakukan pada awal penelitian menunjukkan bahwa konsentrasinya rendah, yakni $0.29 \% \mathrm{C}$ dan $0.03 \% \mathrm{~N}$, kandungan $\mathrm{P}_{2} \mathrm{O}_{5}$ sekitar $43 \mathrm{mg} / 100 \mathrm{~g}$ dan $\mathrm{K}_{2} \mathrm{O} 33 \mathrm{mg} / 100 \mathrm{~g}$. Salah satu metoda yang dipandang tepat untuk memulihkan kembali (remediasi) lahan bekas lumpur tailing ini adalah Fitoremediasi menggunakan tanaman yang berasosiasi dengan mikroba ${ }^{1}$.

Fitoremediasi telah diakui sebagai salah satu teknologi yang murah untuk menghilangkan kontaminan toksik dari tanah. Tanaman akan memfasilitasi reduksi kontaminan dengan menyediakan lingkungan optimal untuk perbanyakan mikroba di zona $a a^{2}$. Di rhizosphere, gula dan asam amino dilepaskan secara langsung dari akar tanaman dalam bentuk exudat atau dengan menggunakan akar untuk tempat pertumbuhan mikroba. Proses degradasi ini tidak hanya dipengaruhi oleh mikroba rhizosphere, tetapi juga oleh peran unik dari tanaman sebagai host ${ }^{3)}$. Jika tanaman berhasil tumbuh pada tanah yang tercemar, maka kombinasi tanaman dengan mikroba di rhizosphere akan merupakan metoda yang ekonomis untuk meningkatkan biodegradasi dari kontaminan yang komplek.

Berbagai studi telah dilakukan untuk 
menguji introduksi bakteri pendegradasi kontaminan (secara natural ataupun telah dimodifikasi genetiknya) untuk meningkatkan kecepatan biodegradasi di area tercemar 2,4,5,6). Hasil penelitian menggunakan tanaman yang bersifat cyanogenic yaitu Sorghum bicolor dan Linum usitatissimum di rumah kaca memperlihatkan kemampuan mereduksi $85 \%$ sianida dalam tanah selama 200 hari tanam. Dengan mengevaluasi alur degradasi ${ }^{7)} \mathrm{C}$-Prussian blue meggunakan growth chamber, ditunjukkan bahwa sekitar $50 \%$ dari target kontaminan dikeluarkan melalui daun sebagai radio-labeled carbon dioxide. Dari penelitian tersebut juga ditemukan berbagai populasi mikroba dalam rhizosfer, antara lain adalah Rhodococcus sp., Bacillus sp., Rhizobium sp., Arthrobacter sp, Pseudomonas sp., dan Microbacterium $\mathrm{sp}$. Alur degradasi sianida oleh Rhodococcus sp., Bacillus sp., dan Microbacterium sp., dipelajari dan ditemukan bahwa produk akhir dari reaksi oksidasi sianida adalah $\mathrm{CO}_{2}$ dan $\mathrm{NH}_{3}$ (amonia). Mikroorganisme lain juga telah diketahui mempunyai aktivitas katabolik yang bervariasi yang dapat digunakan untuk meremediasi sianida anorganik dan nitril. Misalnya penggunaan bakteri penambat $\mathrm{N}$ (Cyanobacteria) untuk biodegradasi sianida telah dilakukan dalam secondary atau tertiary treatment dan hasilnya cukup baik $^{8)}$. Dari temuan diatas mengindikasikan bahwa penggunaan tanaman cyanogenic serta interaksinya dengan mikroba dapat digunakan sebagai salah satu cara yang cukup efisien dalam mengurangi pencemaran sianida di tanah.

Dalam rangka upaya remediasi lahan bekas Tailing di PT Antam Cikotok telah dilakukan serangkaian penelitian Fitoremediasi menggunakan berbagai jenis tanaman dan mikroba yang mempunyai fungsi penyubur tanaman dan pendegradasi sianida. Salah satu jenis tanaman yang digunakan adalah Jati super. Jati super (Tectona grandis L.f) termasuk dalam famili Verbenaceae. Jati super adalah nama dagang dari salah satu jenis pohon
Jati unggul yang dikembangkan dari induk yang berasal dari Thailand. Tanaman ini mempunyai kemampuan tumbuh cepat sehingga mempunyai potensi untuk dapat dimanfaatkan sebagai tanaman agen Fitoremediasi. Disamping itu tanaman Jati super memiliki nilai ekonomi yang cukup tinggi.

Penelitian ini dilakukan untuk mempelajari efek pemberian pupuk organik dan inokulan mikroba terhadap pertumbuhan tanaman serta pengaruhnya secara keseluruhan dalam mengurangi konsentrasi sianida dalam tanah.

\section{BAHAN DAN CARA KERJA}

\subsection{Bahan - bahan yang digunakan dalam penelitian}

\section{1) Tanaman}

Tanaman yang digunakan dalam penelitian ini adalah Jati super (Tectona grandis L.f.).

\section{2) Pupuk organik}

Pupuk organik yang digunakan adalah kompos campuran antara serasah dedaunan yang ada di Kebun Raya Bogor dan pupuk kandang (dari kotoran sapi dan kambing) dengan perbandingan 3:1.

\section{3) Inokulan mikroba}

Inokulan mikroba yang ditambahkan kedalam pupuk organik, merupakan campuran dari 4 kelompok mikroba yaitu : 1) bakteri pendegradasi $\mathrm{CN}, 2$ ) bakteri penambat $\mathrm{N}$ (free living) yang resisten terhadap sianida, 3) bakteri pelarut pospat (Pseudomonas) dan bakteri penambat $\mathrm{N}$ (Rhizobium).

\subsection{Metode}

\section{1) Rancangan percobaan}

Luas petak percobaan $3 \mathrm{~m} \times 4 \mathrm{~m}$, tiap petak ditanami 9 tanaman Jati super. Untuk setiap tanaman diujikan 3 macam perlakuan 
yaitu :

K0 (kontrol, tanpa pemberian pupuk organik),

K1 (pemberian pupuk organik)

K2 (pupuk organik + inokulan mikroba). Masing-masing perlakuan 3 kali ulangan. Rancangan percobaan adalah acak lengkap.

\section{Analisa data}

Data pertumbuhan tanaman dianalisa program SPSS (Statistical Package for the Social Science dan Uji Duncan (0.5\%)

\section{Parameter yang diamati}

a) Pertumbuhan tanaman, yang meliputi: tinggi tanaman, diameter batang dan jumlah daun.

\section{b) Analisis biologi tanah}

Analisa biologi tanah dilakukan dengan menghitung mikroba dalam tanah, yang meliputi total bakteri, bakteri denitrifikasi dan bakteri penambat N (NFB). Jumlah bakteri denitrifikasi dihitung menggunakan metoda Most Probable Number(MPN), menggunakan medium Giltay. Pertumbuhan bakteri denitrifikasi (+) ditandai dengan berubahnya media menjadi biru dan terbentuknya gas pada tabung durham. Kemudian ditentukan jumlah tabung positif dari masing-masing pengenceran berturutturut dari 3 seri pengenceran. Jumlah bakteri untuk tiap gram tanah didasar kan pada jumlah tabung positif dari 3 seri pengenceran yang berturut-turut dan faktor pengencerannya menurut daftar MPN.

Jumlah total bakteri dihitung mengikuti metoda plate count menggunakan medium Nutrient Agar (NA). Sedangkan jumlah bakteri penambat $\mathrm{N}$ dihitung mengikuti metoda plate count, menggunakan medium NFB.

\section{c) Analisa kimia tanah.}

Analisa kimia tanah dilakukan dengan mengukur kandungan hara tanah, seperti nitrogen $\left(\mathrm{NH}_{4}, \mathrm{NO}_{2}, \mathrm{NO}_{3}\right)$ dan sianida $(\mathrm{CN}-$ ).
Konsentrasi Amonium $\left(\mathrm{NH}_{4}-\mathrm{N}\right)$ dan Nitrit $\left(\mathrm{NO}_{2}-\mathrm{N}\right)$ dan Nitrat $\left(\mathrm{NO}_{3}-\mathrm{N}\right)$ ditentukan dengan menggunakan metoda yang tercantum dalam Standard Method ${ }^{9}$ dengan sedikit dimodifikasi. Konsentrasi nitrat ditentukan dengan menggunakan metoda yang tercantum dalam SNI, ${ }^{10)}$ yang telah dimodifikasi ${ }^{11)}$. Sianida dalam tanah dianalisa dengan menggunakan metoda spektrofotometri di laboratorium Balai Besar Pasca Panen, Badan Litbang Pertanian, Cimanggu.

\section{HASIL}

\subsection{Pertumbuhan tanaman}

\section{1) Tinggi tanaman}

Tinggi tanaman meningkat dari bulan Mei hingga Desember, peningkatan tertinggi dicapai oleh tanaman yang diperlakukan dengan kompos organik dan inokulan mikroba (K2), diikuti oleh tanaman yang diperlakukan dengan kompos organik (K1) dan tanaman kontrol (K0) (Gambar 1). Hasil analisa data pengamatan tinggi tanaman pada bulan Desember (umur 7 bulan) terlihat adanya perbedaan yang nyata pada ketiga perlakuan tersebut (Gambar 2). Tinggi tanaman pada perlakuan K2 lebih tinggi dibandingkan dengan perlakuan $\mathrm{K} 1$ dan $\mathrm{K} 0$, demikian juga tanaman Jati super dengan perlakuan K1 lebih tinggi dibandingkan dengan perlakuan K0.

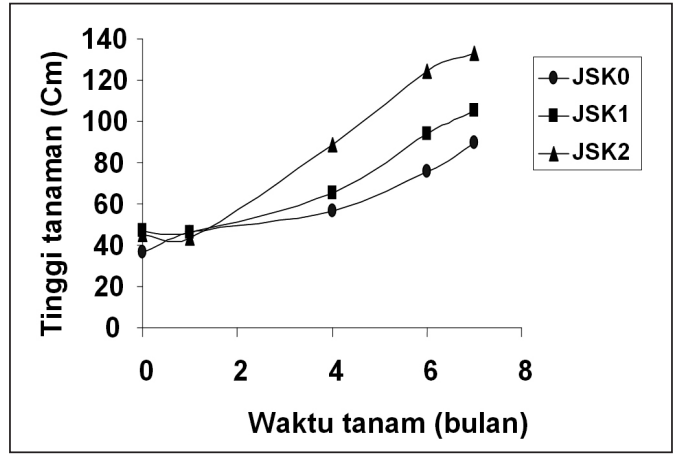

Gambar 1 . Pertambahan Tinggi Tanaman Jati (T. grandis L.f) selama 7 bulan ditanam. 


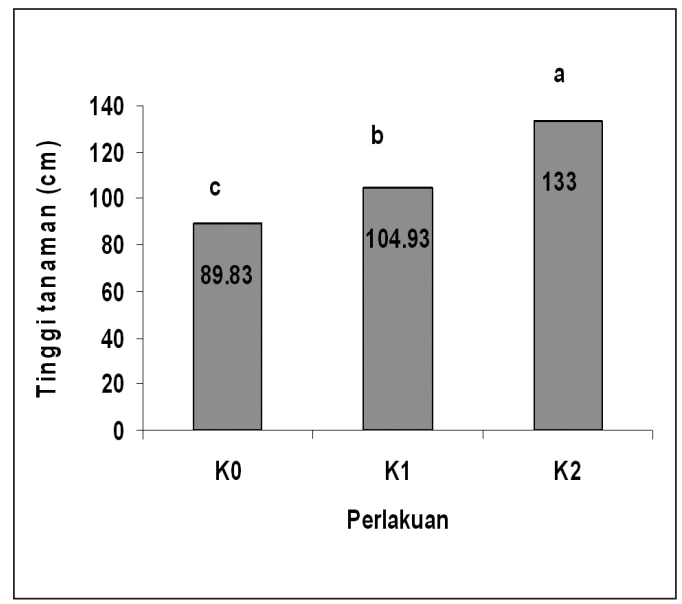

Gambar 2. Analisa Data Tinggi Tanaman Jati (T.grandis L.f) setelah 7 Bulan Ditanam.

\section{2) Jumlah Daun}

Jumlah daun yang diamati setiap bulan menunjukkan bahwa pada perlakuan K2, pertambahan daun Jati super terlihat lebih cepat dibandingkan dengan pada perlakuan K1 dan K0 (Gambar 2). Hasil analisa data rata-rata jumlah daun pada tanaman umur 7 bulan, pada perlakuan K2 lebih banyak dan berbeda nyata dibandingkan dengan perlakuan K0 dan K1. Sedangkan ratarata jumlah daun pada tanaman Jati super pada perlakuan K1 tidak berbeda nyata bila dibandingkan dengan perlakuan K0 (Gambar 4).

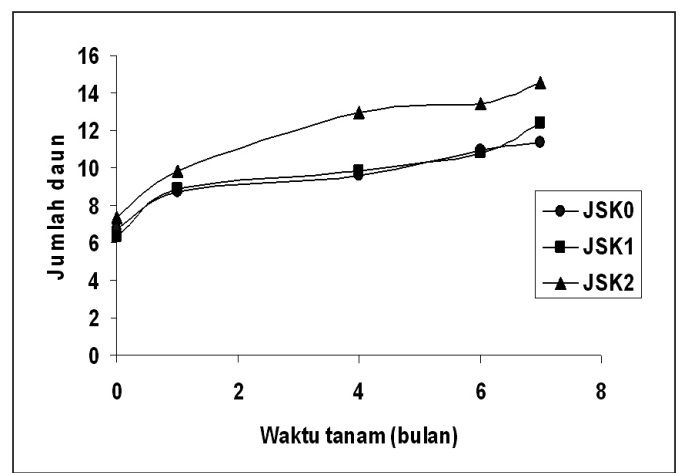

Gambar 3. Petambahan Jumlah Daun Jati (T.grandis L.f) setelah 7 Bulan Ditanam

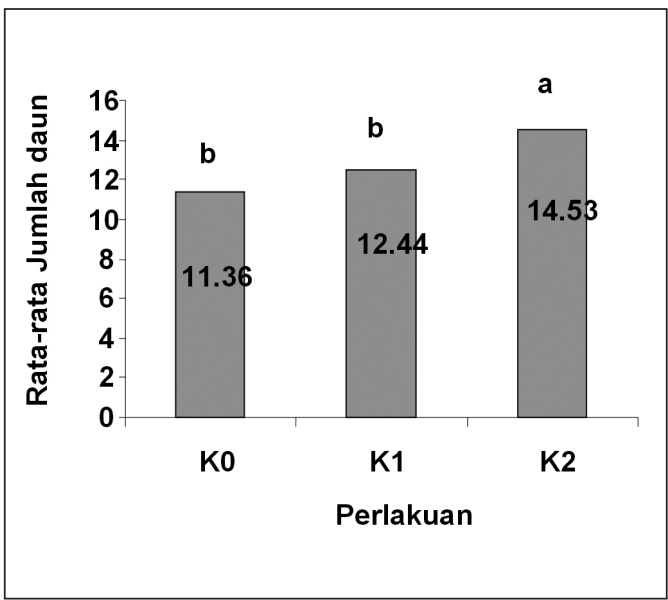

Gambar 4. Analisa Data Jumlah Daun Jati (T.grandis L.f) setelah 7 Bulan Ditanam.

\section{3) Diameter batang}

Pada saat tanaman berumur 2 bulan, diameter batang tanaman Jati super pada perlakuan K0, K1 maupun K2 hampir sama, tetapi perlahan-lahan diameter tanaman pada perlakuan K1 dan K2 mulai terlihat lebih besar dibandingkan dengan kontrol (K0). Diameter batang tanaman Jati super setelah umur 7 bulan pada perlakuan K2 jauh lebih besar bila dibandingkan dengan perlakuan K1 dan K0. Diameter batang tanaman pada perlakuan K1 lebih besar dan berbeda nyata dengan tanaman pada perlakuan K0 (Tabel 3).

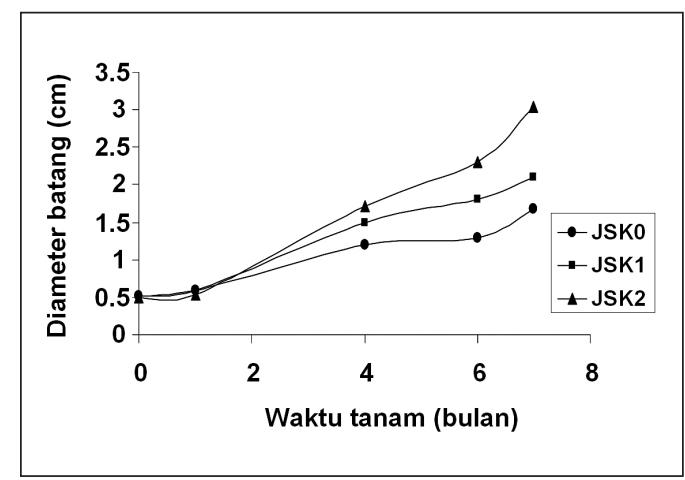

Gambar 5. Pertambahan Diameter Batang Jati(T.grandis L.f) selama 7 Bulan Ditanam 


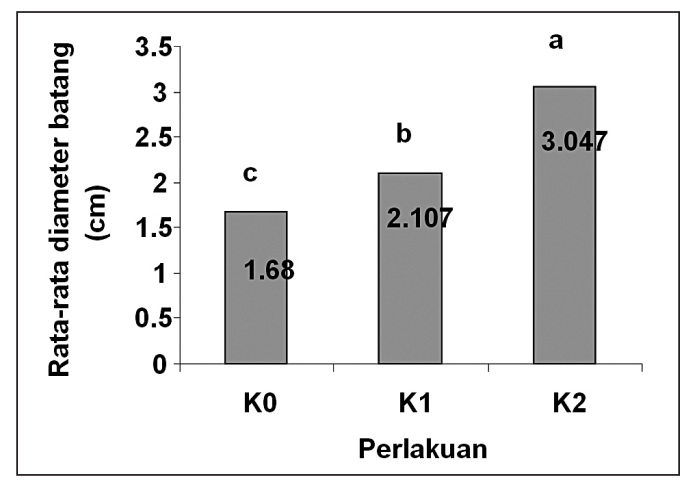

Gambar 6. Analisa Data Diameter Batang Jati (T.gandis L.f) setelah 7 Bulan Ditanam

\section{4) Analisa Tanah}

\section{a. Analisa Biologi Tanah}

Analisa biologi tanah dilakukan dengan menghitung jumlah total bakteri dalam tanah pada 2 bulan, 4 bulan dan 6 bulan setelah tanam. Jumlah bakteri total cukup tinggi,

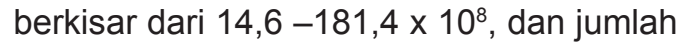
tertinggi terdapat pada tanah yang diberi inokulan mikroba (K2). Seiring dengan berjalannya waktu tanam, jumlah total bakteri memperlihatkan sedikit penurunan menjadi $10^{7}$. Jumlah total bakteri pada perlakuan K0, $\mathrm{K} 1$ dan $\mathrm{K} 2$ tidak nampak adanya perbedaan yang signifikan (tabel 1).

Tabel 1. Perubahan Jumlah Bakteri Total Pada Tanah

\begin{tabular}{|l|l|l|l|l|}
\hline \multirow{2}{*}{ Perlakuan } & \multicolumn{4}{|c|}{ Rata-rata jumlah total bakteri } \\
\cline { 2 - 5 } & $\mathbf{A w a l}$ & $\begin{array}{c}\mathbf{2} \\
\text { bulan }\end{array}$ & $\mathbf{4}$ bulan & $\begin{array}{c}\mathbf{6} \\
\text { bulan }\end{array}$ \\
\cline { 2 - 5 } & $\mathbf{( x ~ 1 0 ^ { 8 } )}$ & $\mathbf{( \times \mathbf { 1 0 } ^ { 7 } )}$ & $\left(\mathbf{\times ~ \mathbf { 1 0 } ^ { 7 } )}\right.$ & $\left.\mathbf{( x ~ 1 0 ~}^{\mathbf{7}}\right)$ \\
\hline JSK 0 & 118,5 & 7,4 & 48,9 & 15,9 \\
\hline JSK 1 & 14,6 & 9,5 & 28,0 & 10,9 \\
\hline JSK 2 & 181,4 & 5,5 & 12,9 & 89,2 \\
\hline
\end{tabular}

Jumlah bakteri penambat N (NFB) pada awal tanam cukup tinggi yaitu $10^{7}$, sejalan dengan pertumbuhan tanaman jumlah bakteri mengalami penurunan menjadi $10^{4}$ setelah 6 bulan tanamn. Penurunan jumlah bakteri penambat $\mathrm{N}$ kemungkinan karena konsentrasi amonium dalam tanah meningkat. Konsentrasi amonium yang tinggi biasanya menjadi faktor penghambat pertumbuhan bakteri penambat N (tabel 2).

Tabel 2. Perubahan Jumlah Bakteri Penambat N (NFB) Pada Tanah Percobaan Selama 6 Bulan

\begin{tabular}{|c|c|c|c|}
\hline \multirow{3}{*}{ Perlakuan } & \multicolumn{3}{|c|}{$\begin{array}{c}\text { Rata-rata jumlah bakteri } \\
\text { NFB } \\
\end{array}$} \\
\hline & Awal & 2 bulan & 6 bulan \\
\hline & $\left(\times 10^{7}\right)$ & $\left(x 10^{6}\right)$ & $\left(\times 10^{4}\right)$ \\
\hline JSK 0 & 75,7 & 33,8 & 60,7 \\
\hline JSK 1 & 31,1 & 25,9 & 18,4 \\
\hline JSK 2 & 356,2 & 1,78 & 61,6 \\
\hline
\end{tabular}

Jumlah bakteri denitrifikasi di dalam tanah percobaan sejak awal relatif rendah, hanya $10^{3}$, dan jumlah tertinggi terdapat pada tanah K2. Setelah 6 bulan, jumlah bakteri denitrifikasi tidak banyak mengalami perubahan, nampak sedikit meningkat pada tanah K0 dan K1, sedangkan pada tanah K2 mengalami sedikit penurunan.(tabel 3 )

\section{Tabel 3.Perubahan Jumlah Bakteri Denitrifikasi Pada Tanah Percobaan selama 6 Bulan}

\begin{tabular}{|c|c|c|c|c|}
\hline \multirow[b]{2}{*}{ Perlakuan } & \multicolumn{4}{|c|}{ Rata-rata jumlah bakteri denitrifikasi } \\
\hline & $\begin{array}{c}\text { Awal } \\
\left(\times 10^{3}\right)\end{array}$ & $\begin{array}{l}2 \text { bulan } \\
\left(\times 10^{3}\right)\end{array}$ & $\begin{array}{l}4 \text { bulan } \\
\left(\times 10^{3}\right)\end{array}$ & $\begin{array}{l}6 \text { bulan } \\
\left(\times 10^{3}\right)\end{array}$ \\
\hline JSKO & 78 & 20 & 136 & 232 \\
\hline JSK1 & 11 & 105 & 183 & 536 \\
\hline JSK2 & 780 & 30 & 123 & 85 \\
\hline
\end{tabular}

\section{b. Analisa Kimia Tanah}

Analisa kimia tanah dilakukan dengan mengamati perubahan konsentrasi unsur kimia dalam tanah percobaan. Pemberian pupuk organik diharapkan mampu mensuplai unsur hara, dan inokulan mikroba yang ditambahkan dalam pupuk organik diharapkan mampu melakukan aktivitas penambatan $\mathrm{N}$, melarutkan pospat dan mendegradasi senyawa sianida dalam 
tanah. Dari asumsi tersebut maka tanah yang diperlakukan dengan pupuk organik (JSK1), pupuk organik plus inokulan (JSK2) dan tanah tanpa pemberian inokulan (JSKO) diduga akan terjadi perubahan unsur-unsur kimia, diantaranya unsur nitrogen dan posfat. Hasil pengamatan perubahan konsentrasi nitrogen (amonium, nitrit dan nitrat) dalam tanah selama 7 bulan ditampilkan pada gambar 7, 8 dan 9 .

\section{Perubahan konsentrasi Amonium dalam tanah}

Pada tanah yang ditanami Jati super, nampak konsentrasi amoniumnya mengalami penurunan setelah 1 bulan tanam (Juni). Pada bulan Juli dan September konsentrasi amonium naik, dan peningkatan amonium lebih tinggi pada perlakuan JSK1 dan JSK2, sedangkan pada tanah JSKO konsentrasi ammoniumnya lebih rendah. Konsentrasi ammonium pada tanah setelah 7 bulan tanam (Nopember) menurun (gambar 7).

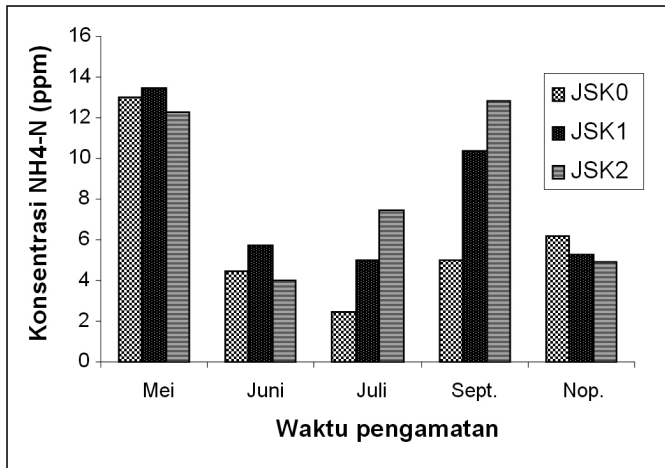

Gambar 7. Perubahan konsentrasi amonium dalam tanah percobaan.

Pemberian pupuk organik secara terpisah ataupun bersama dengan inokulan mikroba pada tanah percobaan berpengaruh terhadap perubahan ammonium dalam tanah. Konsentrasi amonium pada tanah percobaan pada awalnya mengalami penurunan, hal ini kemungkinan karena digunakan untuk pertumbuhan tanaman atau terurai dalam proses nitrifikasi. Setelah 5 bulan tanam konsentrasi amonium pada tanah JSK1 dan JSK2 mengalami peningkatan, hal ini kemungkinan karena penambahan pupuk organik. Kemungkinan lainnya adalah adanya konversi senyawa sianida menjadi amonium ${ }^{12}$. Peningkatan konsentrasi amonium dalam tanah pada perlakuan K1 dan K2 berakibat pada pertumbuhan tanaman yang lebih baik.

\section{Perubahan konsentrasi Nitrit dan Nitrat dalam tanah}

Perubahan konsentrasi amonium dalam tanah diikuti oleh perubahan nitrit dan nitrat. Konsentrasi nitrit mengalami penurunan pada 2, 3 dan 5 bulan setelah tanam, tetapi kemudian mengalami peningkatan pada bulan ke 7. Peningkatan konsentrasi nitrit dari ketiga perlakuan berbeda, dan perlakuan $\mathrm{K} 1$ nampak lebih tinggi peningkatannya diikuti K2 dan K0 (Gambar 8). Sedangkan konsentrasi Nitrat di dalam tanah cenderung naik pada semua perlakuan, dan peningkatan Nitrat yang tertinggi terjadi pada perlakuan K2 diikuti oleh K0 dan K1. (Gambar 9)

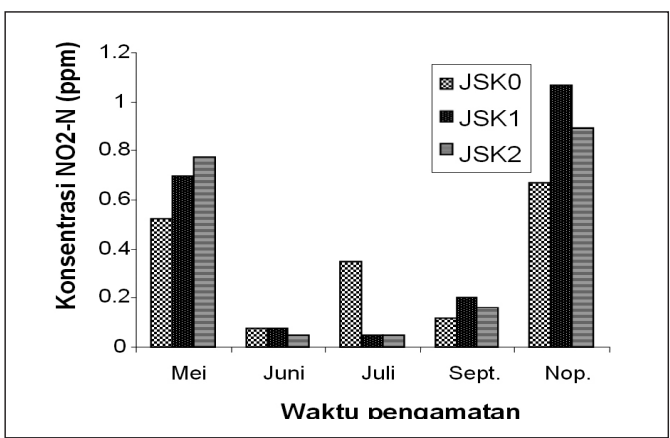

Gambar 8. Perubahan konsentrasi nitrit dalam tanah percobaan Jati (T.grandis L.f)

3. Perubahan konsentrasi sianida pada tanah percobaan

Konsentrasi HCN pada tanah bekas Tailing Pond saat awal tanam, sebelum diberi perlakuan pupuk organik (Mei) mencapai 


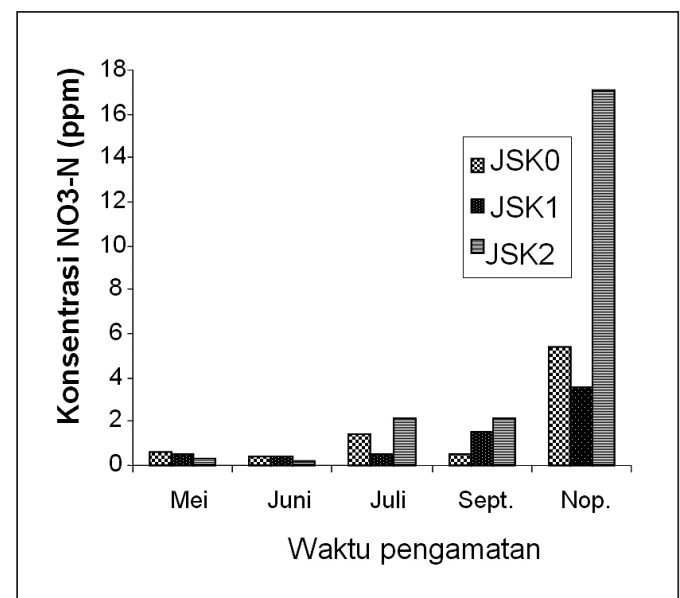

Gambar 9. Perubahan konsentrasi sianida dalam tanah percobaan Jati

sekitar 1,06 ppm (Tabel 4). Konsentrasi sianida setelah 5 bulan tanam (September) terjadi penurunan. Konsentrasi sianida pada tanah yang ditanami Jati super tanpa pemberian pupuk organik (JSKO) megalami penurunan menjadi 0,792 ppm, demikian pula pada tanah yang diberi perlakuan pupuk organik saja (JSK1). Sedangkan pada tanah yang diberi perlakuan pupuk organik plus inokulan mikroba, konsentrasi HCN tidak terdeteksi lagi $(<0,001 \mathrm{ppm})$.

Tabel 4. Konsentrasi sianida pada tanah percobaan

\begin{tabular}{|l|l|l|}
\hline \multirow{3}{*}{ Perlakuan } & \multicolumn{2}{|c|}{$\begin{array}{c}\text { Konsentrasi HCN } \\
\text { (ppm) }\end{array}$} \\
\cline { 2 - 3 } & \multicolumn{1}{|c|}{ Awal } & \multicolumn{1}{|c|}{$\mathbf{5}$ bulan } \\
\hline III JSK0 & 1,06 & 0,792 \\
\hline III JSK1 & 1,06 & 0,792 \\
\hline III JSK2 & 1,06 & $\operatorname{Ttd}(<0,001)$ \\
\hline
\end{tabular}

\section{Perubahan konsentrasi beberapa unsur kimia tanah}

Hasil analisa kimia tanah setelah 5 bulan tanam menunjukkan bahwa konsentrasi karbon (C) dan nitrogen (N) pada tanah yang diberi perlakuan pupuk organik dan inokulan mikroba (K2) cenderung lebih rendah dibandingkan tanah tanpa perlakuan
(K0) dan tanah yang diberi perlakuan pupuk organik (K1) (Tabel 5).

Tabel 5. Konsentrasi beberapa unsur kimia tanah setelah 5 bulan tanam

\begin{tabular}{|l|l|l|l|l|l|l|}
\hline Sampel & $\mathbf{H}_{2} \mathbf{O}$ & $\mathbf{K C l}$ & $\mathbf{C}(\%)$ & $\begin{array}{c}\mathbf{N} \\
(\%)\end{array}$ & $\begin{array}{l}\mathbf{C} / \mathbf{N} \\
(\%)\end{array}$ & $\mathbf{P}_{\mathbf{2}} \mathbf{O}_{\mathbf{5}}$ \\
\hline JSK0 & 8,1 & 7,4 & 0,77 & 0,07 & 11 & 95 \\
\hline JSK1 & 8,1 & 7,3 & 0,74 & 0,07 & 11 & 100 \\
\hline JSK2 & 8,3 & 7,5 & 0,41 & 0,03 & 14 & 57 \\
\hline
\end{tabular}

\section{PEMBAHASAN}

Pertumbuhan tanaman secara keseluruhan seperti yang terlihat pada Gambar 1 - 6 memperlihatkan bahwa pemberian pupuk organik (K1) dan pupuk organik dengan inokulan mikroba (K2) berdampak positif terhadap pertumbuhan tanaman. Hal ini diduga disebabkan oleh adanya aktivitas mikroba-mikroba spesifik pada rhizosfer yang mempunyai peran melarutkan phospat dan menambat $\mathrm{N}$ sehingga nutrien, utamanya nitrogen dan phospor yang dibutuhkan tanaman menjadi tersedia bagi tanaman. Adanya bakteri pendegradasi sianida pada inokulan mikroba akan mengkonversi sianida menjadi bentuk senyawa kimia lain yang tidak toksik sehingga kondisi lingkungan perakaran menjadi lebih baik untuk pertumbuhan. Kemungkinan karena hal tersebut pertumbuhan tanaman Jati super pada perlakuan K2 lebih baik dibandingkan dengan $\mathrm{K} 0$ dan $\mathrm{K} 1$.

Peningkatan konsentrasi nitrit dan nitrat mengindikasikan terjadinya proses nitrifikasi dalam tanah, dan proses nitrifikasi berlangsung lebih baik pada tanah $\mathrm{K} 2$. Sedangkan pada tanah K1 dan K0 kemungkinan proses denitrifikasi terjadi, diindikasikan dengan rendahnya konsentrasi nitrat yang kemungkinan direduksi menjadi gas N. Jumlah bakteri denitrifikasi yang lebih tinggi pada tanah $\mathrm{K} 1$ dan $\mathrm{K} 0$ (Tabel 3) 
memperkuat dugaan tersebut.

Konsentrasi HCN pada awal tanam hanya terdeteksi sekitar 1,06 ppm, konsentrasi ini termasuk rendah dan masih dalam ambang batas yang diperbolehkan. Konsentrasi sianida tersebut mengalami sedikit penurunan setelah 5 bulan tanam. Pada tanah yang ditanami Jati super tanpa pemberian kompos (JSKO) turun menjadi 0,792 ppm, demikian pula pada tanah yang diberi perlakuan kompos (JSK1), sedangkan pada tanah yang diberi perlakuan kompos plus inokulan mikroba, konsentrasi HCN nol atau tidak terdeteksi ( $<0,001 \mathrm{ppm})$. Dari data ini dibuktikan bahwa pemberian inokulan mikroba berpengaruh pada kecepatan eliminasi sianida dalam tanah.

Rendahnya konsentrasi C dan $\mathrm{N}$ pada tanah K2 mengindikasikan terjadinya perombakan bahan organik yang lebih intensif di tanah yang diberi inokulan mikroba. Perombakan bahan organik pada tanah kemungkinan juga dibarengi dengan perombakan sianida dalam tanah yang dilakukan oleh mikroba pendegradasi sianida yang terdapat dalam inokulan. Adanya perombakan sianida menyebabkan kandungan sianida pada tanah yang diberi pupuk organik dan inokulan mikroba (K2) menjadi lebih rendah dibanding perlakuan lainnya (Tabel 4).

Unsur $\mathrm{P}\left(\mathrm{P}_{2} \mathrm{O}_{5}\right)$ dalam tanah juga lebih rendah pada tanah $\mathrm{K} 2$ dibanding $\mathrm{K} 0$ dan K1. Bakteri pelarut pospat dalam inokulan berperan merubah bentuk persenyawaan $P$ yang tidak tersedia menjadi tersedia bagi tumbuhan. $\mathrm{P}$ dalam tanah yang diserap tumbuhan dalam bentuk ion $\mathrm{H}_{2} \mathrm{PO}_{4}^{-}$dan $\mathrm{HPO}_{4}^{2-7,10)}$. Akibat dari perubahan bentuk $\mathrm{P}$ tersebut maka pada tanah $\mathrm{K} 2$ konsentrasi $\mathrm{P}_{2} \mathrm{O}_{5}$ menjadi lebih rendah dibanding dengan tanah $\mathrm{K} 1$ dan $\mathrm{K} 0$.

\section{KESIMPULAN}

Hasil penelitian menunjukkan bahwa pemberian pupuk organik dan inokulan mikroba berpengaruh positif terhadap pertumbuhan tanaman Jati super di tanah bekas Tailing pond, PT Antam Cikotok. Tinggi tanaman meningkat sekitar $48 \%$, jumlah daun sekitar $28 \%$ dan dimeter batang meningkat hingga mencapai sekitar $81 \%$. Pemberian pupuk organik dan inokulan mikroba pada tanah juga memperlihatkan efek positif terhadap perubahan unsur-unsur kimia tanah yang berguna bagi pertumbuhan tanaman. Pemberian inokulan mikroba juga meningkatkan kemampuan eliminasi sianida dalam tanah, yaitu sekitar $25 \%$ lebih tinggi dibandingkan dengan perlakuan yang hanya menggunakan pupuk organik. Namun demikian pemberian inokulan mikroba dan pupuk organik tidak berpengaruh signifikan terhadap populasi mikroba dalam tanah.

\section{UCAPAN TERIMA KASIH}

Penulis mengucapkan terima kasih kepada sdri Nani Mulyani dan Arie Rosmalina dan teman-teman TU Bioremediasi yang telah membantu dari awal hingga selesainya penelitian ini. Penelitian ini dibiayai oleh dana DIPA, Puslit Biologi-LIPI.

\section{DAFTAR PUSTAKA}

1. Stephen Ebbs. 2004. Biological degradation of cyanide compounds. www. sciencedirect.com

2. Hanson, KG., N Anuranjini, K. Madlavi and J.D. Anjana. 1997. Bioremediation of Crude oil contamination with Acinetobacter sp A3. Curr.Microbiol, 35 : 191 - 193

3. Chaudhry,Q., M.Blom-Zandstra, S. Gupta and E.J. Joner. 2005. Utilising the synergy between plants and rhizosphere microorganism to enchance breakdown of organic pollutans in the environment. Environ.Sci.Pollut.Res. Int, 12 : 34- 48 
4. Sommers, E., L.Vanderleyden and M. Srinivasan. 2004. Rhizosphere bacterial signaling : A love parade beneath our feet. Crit. Rev.Microbiol ., 30 : 205 $-240$

5. Tesema, G., L.R. Vough and R.L. Chaney. 2004. Phytoremediation of polychlorinated biphenyl contaminated soils: The rhizosphere effect. Environ. Int., 30 : $799-804$

6. Wei Shuhe, W., Z. Qixing, Z. Kaisong and L. Jidong. 2003. Roles of rhizosphere in remediation of contaminated soils and its mechanisms. Yingyong Shengtai Xuebao, 14 : 143 - 147

7. Winarso 2005. Kesuburan Tanah Dasar Kesehatan dan Kualitas Tanah. Penerbit Gava Media Yogyakarta

8. Gantzer, CJ and WJ. Maier. 1990. Biological Degradation of Cyanide by NitrogenFixingCyanobacteria.EPA/600/ S2-90/034
9. American Public Health Association. 1992. Standars Methods for the Examination of Wastewater. $18^{\text {th }}$ Ed. APHA. Washington. DC, USA

10. Departemen Pekerjaan Umum. 1990. Kumpulan SNI Bidang Pekerjaan Umum

11. Agustiyani, D dan H. Imamuddin. 2000. Pertumbuhan Kultur Nitrifikasi Campuran Pada Senyawa Amonium. Proseding Seminar Nasional Biologi XVI dan Kongres Nasional Perhimpunan Biologi Indonesia (PBI) XII, Bandung.

12. Basile, LJ. 2008. Cyanide Degrading enzymes for Bioremediation. 2008. Thesis Master of Sciences Texas A \& M University. 